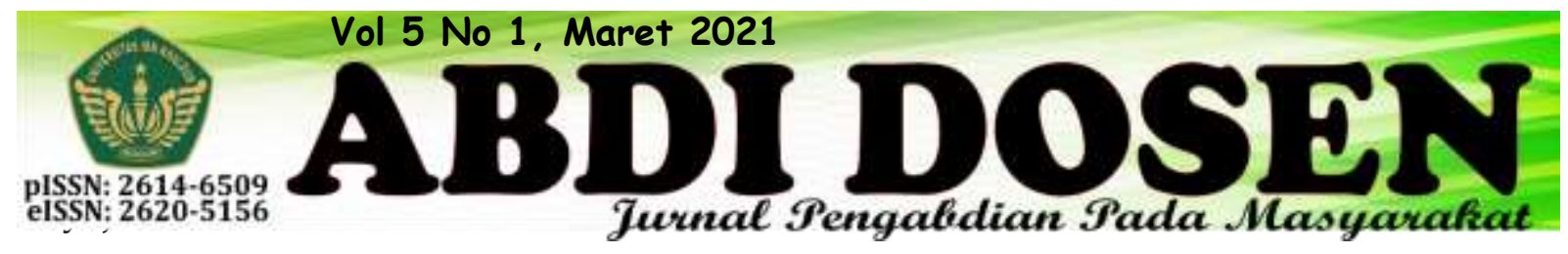

\title{
COVID-19 DI TEMPAT KERJA: UPAYA PENINGKATAN PEMAHAMAN DAN LESSON LEARN PADA MASA PANDEMI DENGAN PENDEKATAN ONLINE LEARNING
}

\author{
David Kusmawan \\ david.kusmawan@unja.ac.id \\ Program Studi Ilmu Kesehatan Masyarakat, Fakultas Kedokteran dan Ilmu Kesehatan, Universitas Jambi \\ Jln. Letjen Suprapto No.33, Telanaipura, Kec. Telanaipura, Kota Jambi, Jambi 36361
}

\begin{abstract}
ABSTRAK
Pengabdian Kepada Masyarakat (PKM) yang dilaksanakan oleh dosen di Program Studi Ilmu Kesehatan Masyarakat Fakultas Kedokteran dan Ilmu Kesehatan (FKIK) Universitas Jambi ini mengangkat tema current situation terkait pandemi COVID-19 di tempat kerja. Pengabdian ini diselenggarakan secara daring dengan metode webinar sebagai salah satu metode kerja di masa pandemi. Tujuan dari pengabdian ini adalah untuk memberikan penyuluhan dari pakar di bidang K3 kepada mahasiswa, pemerhati dan praktisi K3 terkait strategi pencegahan COVID-19 di tempat kerja dari perspektif kesehatan dan keselamatan kerja serta lesson learn dari implementasinya di RSDC Wisma Atlet Jakarta. Strategi yang diterapkan mengacu pada pedoman yang dikeluarkan oleh OSHA, WHO dan ACGIH. Sedangkan lesson learn terkait implementasi K3 di RSDC Wisma Atlet adalah implementasi K3RS di RSDC Wisma Atlet sangat diperlukan dengan berbagai macam pengembangan dan updating kebijakan karena situasi pandemic COVID-19 yang memberikan tantangan tersendiri. Implikasi dari kegiatan Pengabdian Kepada Masyarakat (PKM) webinar nasional dengan tema current condition ini berdasarkan pemaparan dan hasil diskusi via daring atau online learning salah satunya yaitu meningkatkan pemahaman dan awareness peserta terkait COVID-19 di tempat kerja dengan berbagai macam prosedur dan langkah pengendalian yang bisa dilakukan, serta menambah wawasan dan gambaran implementasi K3RS di RSDC Wisma Atlet sebagai RS rujukan COVID-19.
\end{abstract}

Kata kunci: RSDC Wisma Atlet, Pengabdian Masyarakat, COVID-19, Rumah Sakit, Online Learning

\section{ABSTRACT}

This Community Service (PKM) carried out by lecturers at the Jambi University Faculty of Medicine and Health Sciences (FKIK) Public Health Study Program raised the theme of the current situation related to the COVOD-19 pandemic at work. This service was held online with the webinar method as one of the working methods during a pandemic. The purpose of this service is to provide counseling from experts in the field of K3 to students, observers and $K 3$ practitioners regarding strategies for preventing COVID-19 in the workplace from a work health and safety perspective as well as lessons learned from its implementation at RSDC Wisma Atlet Jakarta. The strategy implemented refers to the guidelines issued by OHSHA, WHO and ACGIH. Meanwhile, lessons learned related to the implementation of K3 at the 
Wisma Atlet RSDC are that the implementation of K3RS at the Wisma Atlet Hospital is very much needed with various kinds of policy development and updating because the COVID-19 pandemic situation presents its own challenges. The implication of this national webinar Community Service (PKM) activity with the theme of current conditions is based on the exposure and results of discussions via online or online learning, one of which is increasing the understanding and awareness of participants regarding COVID-19 in the workplace with various kinds of procedures and control measures that can carried out, as well as adding insight and description of the implementation of K3RS at RSDC Wisma Atlet as a COVID-19 reference hospital.

\section{Keyword: RSDC Wisma Atlet, Community Service, COVID-19, Hospital, Online Learning}

\section{PENDAHULUAN}

Organisasi Kesehatan Dunia (WHO) di China menginfokan tentang kasus-kasus pneumonia dari sisi etiologi yang tidak diketahui dan terdeteksi di Kota Wuhan, Provinsi Hubei, China Tengah pada tanggal 31 Desember 2019. Setelah dianalisis dari sampel yang berasal dari swab pernapasan, para ahli di Center Disease Control (CDC) China menyatakan bahwa pneumonia tersebut, yang kemudian dikenal sebagai novel coronavirus pneumonia (NCP) atau COVID-19, yang disebabkan oleh novel coronavirus (WHO, Huang et.al 2019).

Berdasarkan studi analisis filogenetik mengungkapkan bahwa COVID-19 merupakan virus yang berpotensi zoonosis (Rothan et.al 2020). COVID-19 adalah infeksi virus yang sangat mudah menular dan disebabkan oleh sindrom pernafasan akut coronavirus 2 (SARS-CoV-2), yang muncul di Wuhan, China dan menyebar ke seluruh dunia (Khan et. al. 2020). Pandemik global ini telah memberikan dampak yang signifikan bagi seluruh negara di dunia baik dari sisi kesehatan, ekonomi, sosial budaya, dan pendidikan, pekerjaan, pariwisata, industri dsb untuk menerapkan new normal era. Saat ini, Indonesia pun menghadapi pandemi COVID-19 dengan jumlah pasien positif mencapai 772.103 kasus, 22.911 kematian (per 5 Januari 2021).

Sedangkan secara global, pandemik ini telah melumpuhkan hampeir semua negara di dunia dengan dengan total kasus mencapai 85.636.417 kasus (1.853.841 kematian), dimana kasus-kasus tertinggi seperti: Amerika Serikat (21.118.056 kasus, 360.151 kematian), India (10.345.118 kasus, 149.721 kematian), dan Brazil (7.733.746 kasus, 196.018 kematian).

Tempat kerja menjadi salah satu cluster penularan dari virus ini. Berbagai macam pedoman dan panduan dari regulator nasional dan internasional sudah dikeluarkan terkait pencegahan COVID-19 di tempat kerja, pun juga dengan penelitiannya. 


\section{METODE PELAKSANAAN}

Metode penyelenggaraan kegiatan Program Pengabdian Kepada Masyarakat ini berskala nasioal dengan total peserta webinar mencapai 500 orang yang dilakukan dalam bentuk webinar nasional dengan menggunakan aplikasi ZoomMeeting.

Sesi pertama materi dibawakan oleh akdemisi bidang K3 dari Fakultas Ilmu Kesehatan (FIKES) UPN Veteran Jakarta yaitu Ibu Fandita Tonyka Maharani,

\section{HASIL dan PEMBAHASAN}

Pada webinar sesi pertama narasumber memaparkan 3 materi pokok yaitu overview COVID-19, dampak COVID-19 pada pekerja dan terakhir adalah strategi pencegahannya.

Virus SARS-CoV-2 termasuk jenis bahaya biologi yang dapat menular melalui udara (airborne). Mengingat lebih dari $50 \%$ populasi adalah pekerja maka jika pekerja terdampak maka produktivitas dan ekonomi masyarakat bisa terganggu, oleh karena itu para pekerja tersebut perlu mendapatkan perhatian lebih di samping tenaga medis. Di sisi lain penularan juga banyak terjadi pada cluster pekerja, perkantoran dan industri (pabrik) telah banyak dilaporkan. Kemudian pembicara juga menyampaikan piramida risiko paparan dari virus ini mulai dari yang berisiko rendah sampai tinggi
S.KM., M.Sc., M.K.K.K. dengan materi COVID-19 di Tempat Kerja.

Sedangkan pada sesi kedua narasumber yang hadir adalah Mirwansyah, S.K.M. dari tim K3 RSDC Wisma Atlet yang membawakan materi tentang penerapan dan lesson learn implementasi keilmuan K3 di Rumah Sakit Darurat Center Wisma Atlet (RSDC) Jakarta Selatan.

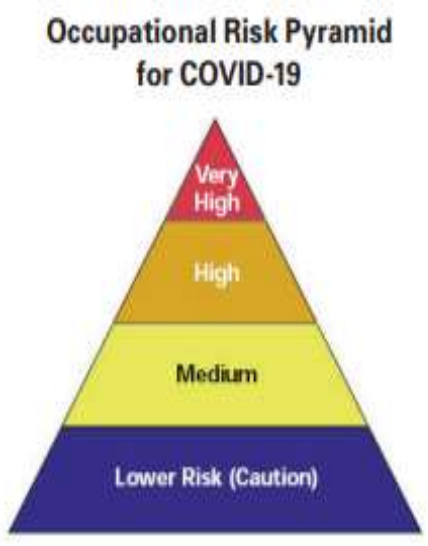

Gambar 1. Pekerja berisiko COVID-19

Golongan berisiko sangat tinggi antara lain Petugas kesehatan (misalnya, dokter, perawat, dokter gigi paramedis, teknisi medis darurat) yang melakukan prosedur yang menimbulkan aerosol (misalnya, intubasi, prosedur induksi batuk, bronkoskopi, beberapa prosedur dan pemeriksaan gigi, atau pengambilan spesimen invasif) pada COVID-19 yang diketahui atau dicurigai pasien. Petugas kesehatan atau laboratorium yang mengumpulkan atau menangani spesimen dari pasien COVID-19 yang diketahui atau dicurigai (misalnya, memanipulasi budaya dari pasien COVID-19 yang diketahui atau dicurigai). Pekerja kamar yang melakukan otopsi, yang umumnya melibatkan 
prosedur yang menimbulkan aerosol, pada tubuh orang yang diketahui memiliki, atau dicurigai mengidap COVID-19 pada saat kematian mereka.

Staf pengantaran dan support staf (Dokter, perawat, dan staf rumah sakit lainnya yang harus memasuki kamar pasien) yang terpapar dengan pasien yang diketahui atau dicurigai COVID-19. (Catatan: ketika pekerja tersebut melakukan prosedur yang menghasilkan aerosol, tingkat risiko paparan mereka menjadi sangat tinggi.)

Pekerja transportasi medis (misalnya, operator kendaraan ambulans) memindahkan pasien yang diketahui atau dicurigai COVID-19 ke dalam kendaraan tertutup.

Pekerja kamar mayat yang terlibat dalam mempersiapkan (misalnya, untuk penguburan atau kremasi) jenazah orang yang diketahui memiliki, atau dicurigai memiliki, COVID-19 pada saat kematian mereka.

Selanjutnya adalah penyampaian materi terkait tingkatan penegndalian (hirarki pengendalian) yang meliputi engineering control (meliputi General dan Local Exhaust Ventilation, kipas angin, filtrasi, pengendalian secara administratif, dan penggunaan dan spesifikasi APD.

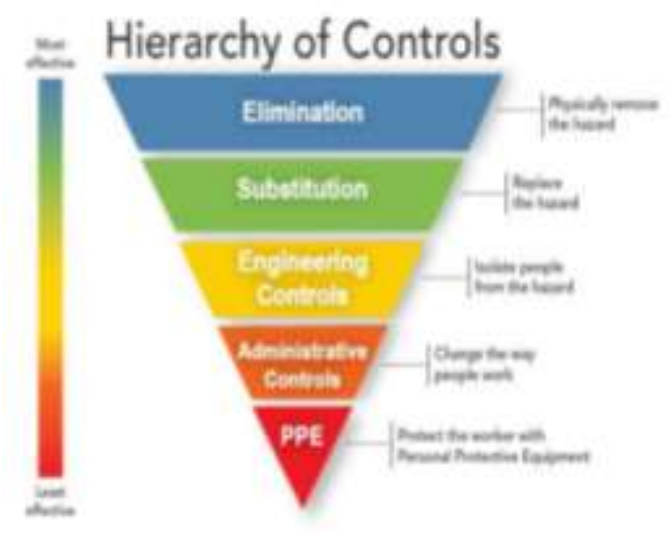

Gambar 2. Hirarki pengendalian bahaya
Pertama Engeenering Control (Kontrol secara rekayasa Teknik) dengan menggunakan Dilution Ventilation. Prinsip kerjanya adalah "mengencerkan" udara yang terkontaminasi Caranya terdiri atas ventilasi alami (pintu, jendela) dan mengganti udara di dalam ruangan dengan udara bersih (menggunakan aliran udara 50-150 feet per menit) serta prinsip campuran.

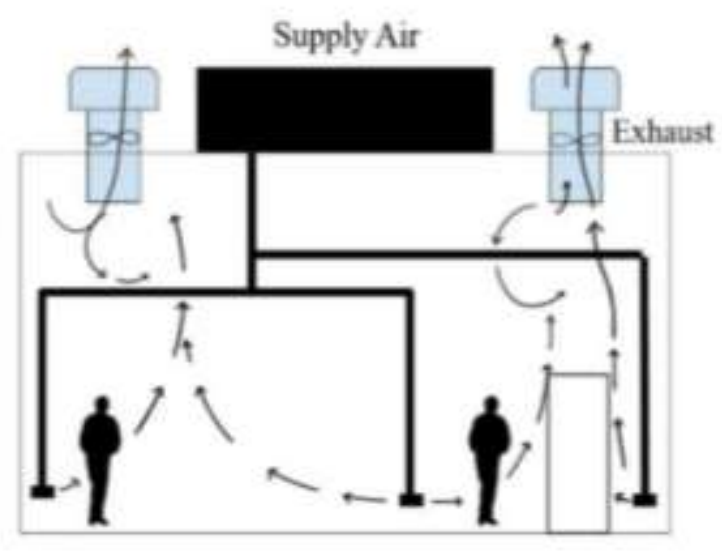

FIGURE 2 Displacement Ventilation

Gambar 3. Penggantian Ventilasi

Kemudian penggunaan LEV, namun hal ini mempunyai kekurangan karena hood harus diletakkan di depan muka pekerja untuk menangkap kontaminan (virus COVID-19)

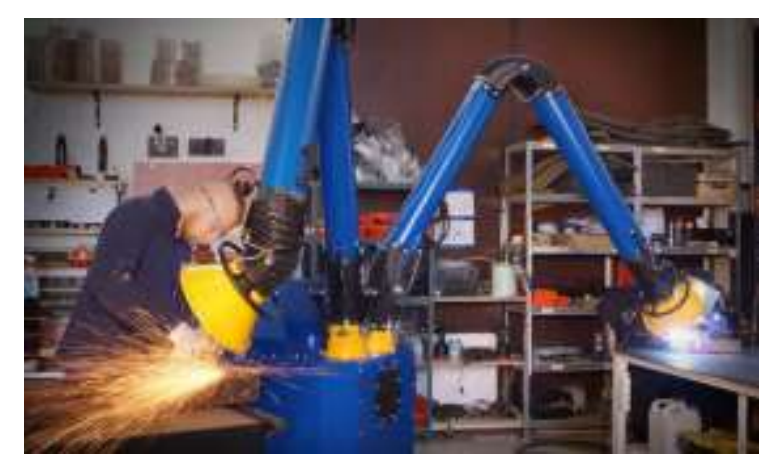

Gambar 4. Penggunaan LEV

Local Exhaust Ventilation

- Penggunaan kipas angin yang 
diletakkan di langit-langit tidak terlalu disarankan karena lebih berisiko meningkatkan penyebaran virus COVID-19 (Jianyun Lu, 2020)

- Keberadaaan kipas angin di dalam industri tidak bisa dihilangkan, karena pekerja bisa berisiko heat stress

- Lebih baik meletakkan kipas angin sedekat mungkin dengan lantai

Selain itu bisa menggunakan metode campuran yakni meletakkan kipas angin di langit-langit dan menggunakan dilution ventilation

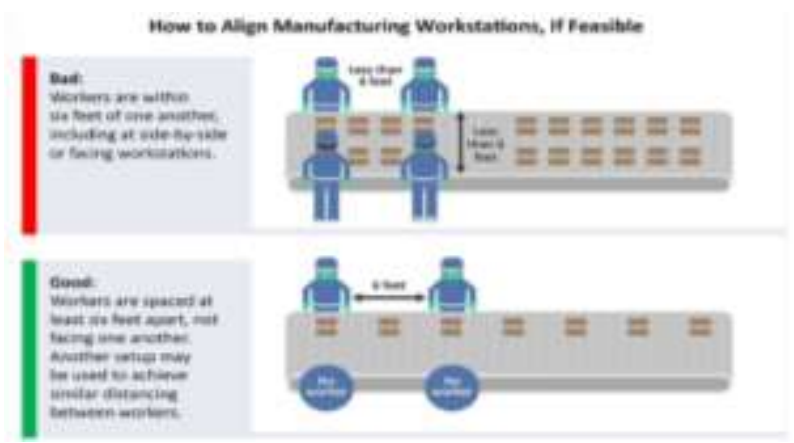

Gambar 5. Skematis penaata pekerja di pabrik/industri

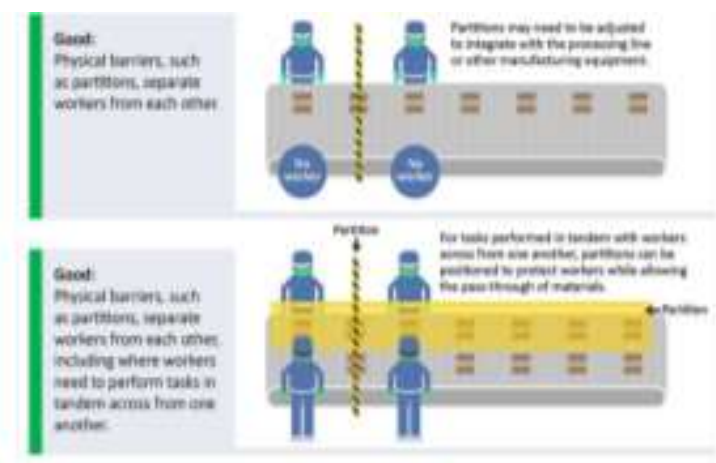

nouke 6. How to Algn Mamblacturing Waikars (CECE, 2629)

Gambar 6. Skematis penaata pekerja di pabrik/industri

$\begin{array}{rrr}\text { Pengendalian } & \text { secara } & \text { secara } \\ \text { administrative } & \text { meliputi } & \text { Program }\end{array}$ disinfektansi berkala, Informasi yang jelas, Pengaturan waktu kerja (shift dsb), kebijakan terkait COVID-19 (apabila sakit dianjurkan di rumah), Pemasangan ramburambu K3, penyediaan fasilitas CTPS, hand sanitizer, Alur komunikasi yang jelas. Terakhir adalah penggunaan Alat Pelindung Diri yang meliputi Respirator N95 dan surgical mask.

Pada sesi pertanyaan juga banyak di bahas detail dari aplikasi pengendalian tersebut. Berikut salah satu pertanyaan yang diajukan oleh peserta terakit kendala yang dihadapi dalam implementasinya.

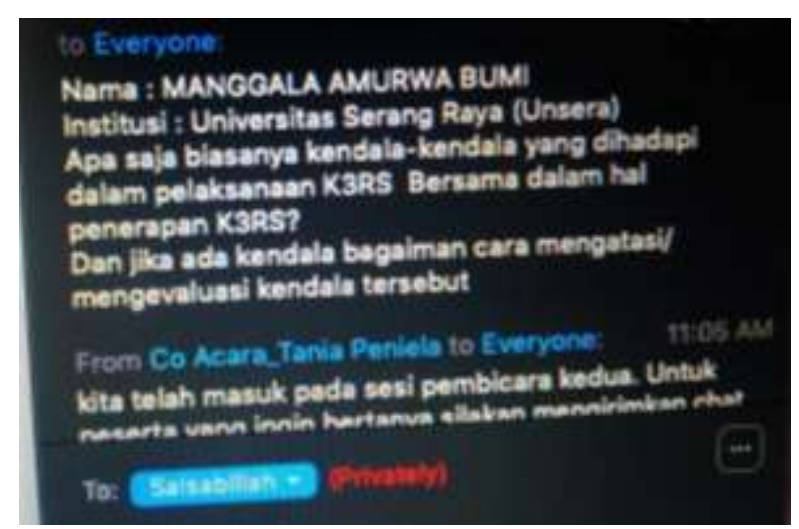

Gambar 7. Contoh Pertanyaan dari peserta PKM

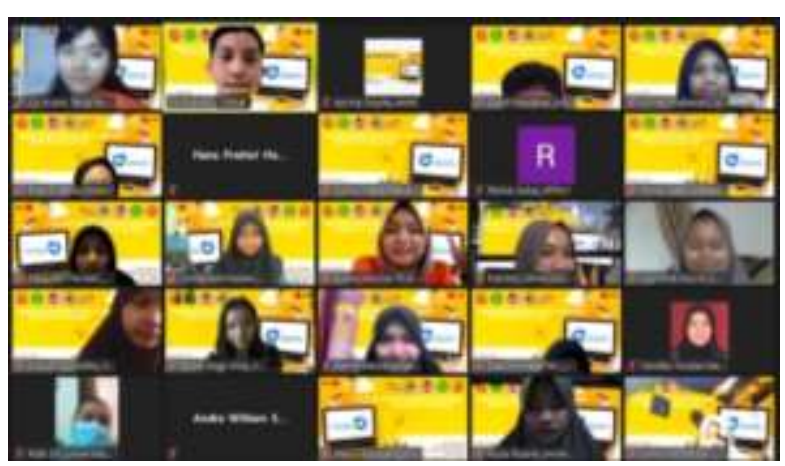

Gambar 8. Dokumentasi sesi terakhir kegiatan PKM

Selanjutnya pemaparan pemateri kedua oleh salah satu tim K3 RSDC Wisma Atlet saudara Mirwan, SKM yang memaparkan materi overview implementasi K3RS di RSDC Wisma Atlet, implementasi manajemen risiko, kegiatan dan program keselamatan dan keamanan, pelayanan kesehatan kerja, pengelolaan limbah B3, pengelolaan sarpras, pencegahan dan pengendalian 
kebakaran, pengelolaan alkes, kesiapsiagaan kondisi darurat bencana, serta kegiatan pendukung yang meliputi morning report, orientasi relawan baru, patrol K3, pemasangan spanduk KTR, pemilhan duta $\mathrm{K} 3$.

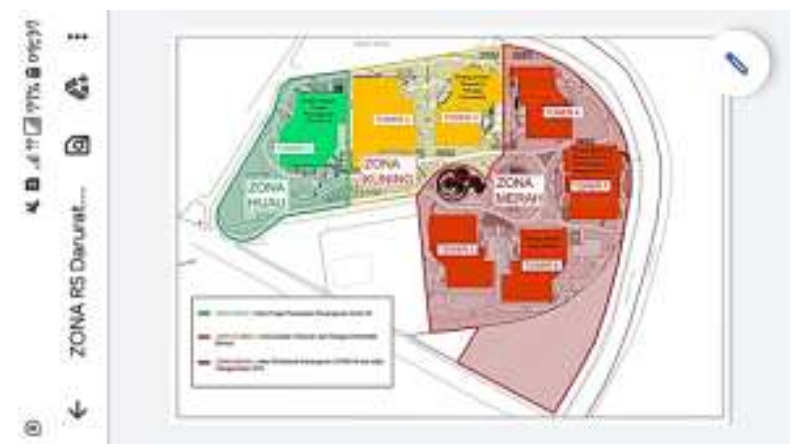

Gambar 9. Peta RSDC Wisma Atlet

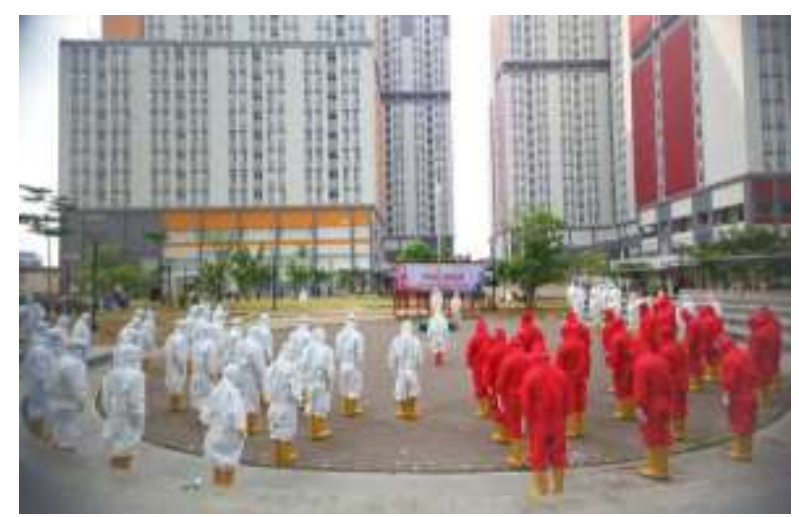

Gambar 10. Tim K3RS RSDC Wisma Atlet

Kegiatan Manajemen Risiko diantara melakukan risk asesesment dan identifikasi bahaya yang ada di RSDC Wisma Atlet dengan pendekatan risk matrix untuk menentukan tingat risikonya sehingga bisa dilakukan pengendalian secara terukur dan tepat. Selanjutnya kegiatan keselamatan dan keamanan dilakukan dengan cara/program safety patrol untuk mengidentifikasi tindakan unsafe act dan dan unsafe condition. Pelayanan Kesehatan Kerja meliputi kegiatan kunjungan ke poliklinik, pelayanan PAK, KAK, MCU, dan kegiatan Swab. Kemudian kegiatan pengelolaan limbah B3 meliputi kegiatan dan program penempelan/pelabelan MSDS untuk semua bahan kimia yang digunakan, kegiatan simulasi Spill Kit, dan program pembuatan SOP pengelolaan limbah B3.

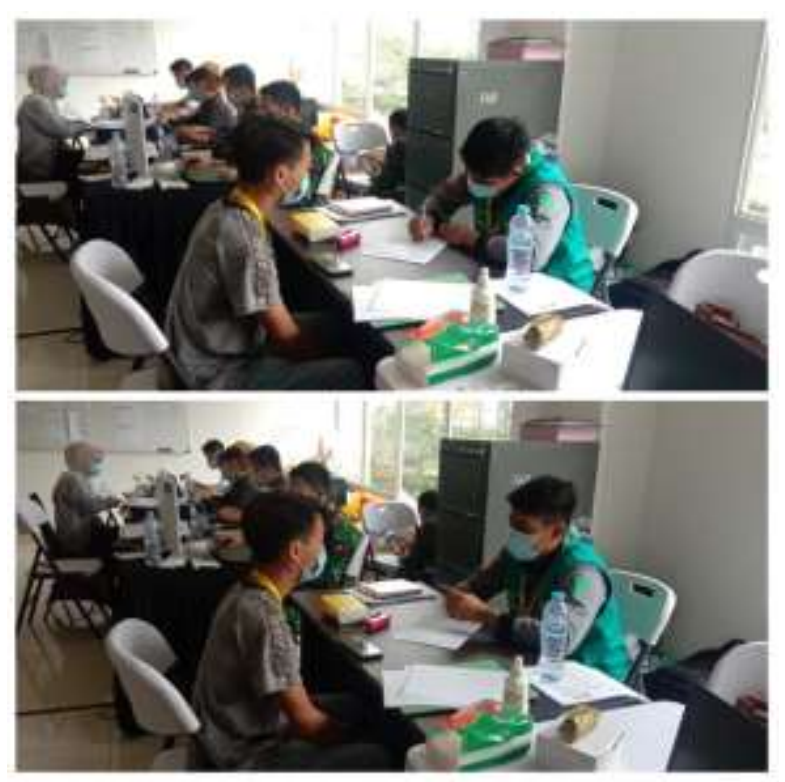

Gambar 11. Kegiatan Pelayanan Kesehatan di RSDC Wisma Atlet

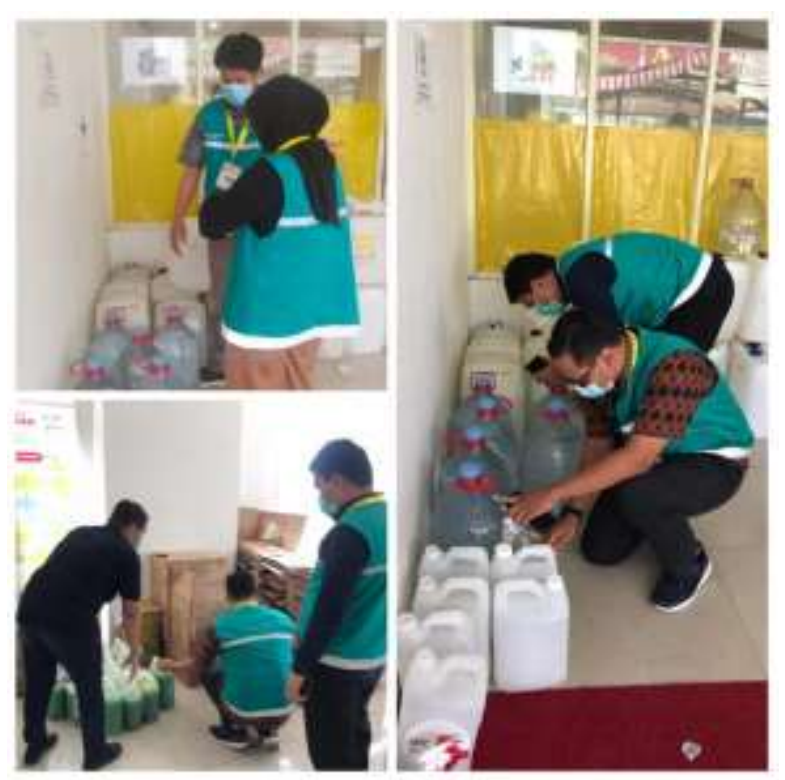

Gambar 12. Kegiatan pelabelan MSDS bahan kimia di RSDC Wisma Atlet 


\section{KESIMPULAN}

Implikasi dari kegiatan Pengabdian Kepada Masyarakat (PKM) webinar nasional dengan tema current condition ini berdasarkan pemaparan dan hasil diskusi via daring adalah meningkatkan pemahaman dan awareness peserta terkait

\section{DAFTAR PUSTAKA}

\section{Buku:}

ACGIH. 2020. White Paper on Ventilation for Industrial Settings during the COVID-19 Pandemic

OSHA. 2020. Guidance on Preparing Workplaces for Covid-19

Kemenkes. 2020. Surat Edaran Nomor HK.02.01/Menkesilil 2020 Tentang Protokol Pencegahan Penularan Corona Virus Disease (COVID-19) di Tempat Kerja

\section{Website:}

WHO. World Health Organization, Pneumonia of unknown cause China. Disease outbreak news: 5 January 2020. 2020

https://www.who.int/newsroom/commentaries/detail/transmis sion-of-sars-cov-2-implicationsfor-infection-preventionprecautions

https://www.who.int/publications/i/item/ad vice-on-the-use-of-masks-in-thecommunity-during-home-care-andin-healthcare-settings-in-thecontext-of-the-novel-coronavirus(2019-ncov)-outbreak
COVID-19 di tempat kerja dengan berbagai macam prosedur dan langkah pengendalian yang bisa dilakukan, serta menambah wawsan dan gambaran implementasi K3RS di RSDC Wisma Atlet sebagai RS rujukan COVID-19.

http://kesjaor.kemkes.go.id/documents/PM K_No._66_ttg_Keselamatan_dan Kesehatan_Kerja_Rumah_Sakit_.p $\underline{d f}$

\section{Artikel Jurnal:}

Huang C, Wang Y, Li X, Ren L, Zhao J, $\mathrm{Hu} \mathrm{Y}$, et al. Clinical features of patients infected with 2019 novel coronavirus in Wuhan, China. Lancet. 2020.

Rothan HA, Byrareddy SN. The epidemiology and pathogenesis of coronavirus disease (COVID-19) outbreak. Journal of Autoimmunity. 2020.

Lu J, Gu J, Li K, Xu C, Su W, Lai Z, Zhou D, Yu C, Xu B, Yang Z. COVID19 outbreak associated with air conditioning in restaurant, Guangzhou, China, 2020. Emerging infectious diseases. 2020 Jul; 26(7):1628.

Khan M, Kazmi S, Bashir A, Siddique N. COVID-19 infection: origin, transmission, and characteristics of human coronaviruses. J Adv Res. 2020. 